\title{
Implementasi Kebijakan Program Pos Pembinaan Terpadu Penyakit Tidak Menular (Posbindu PTM) Di Puskesmas Sinar Baru Pada Tahun 2018
}

\author{
Sudarcun, ${ }^{a 1}$, Mirawati, ${ }^{\text {b2 }}$, Zakiyudin Fikri, ${ }^{\text {3 }}$ \\ aSTISIPOL Pahlawan 12 Sungailiat, Jalan Diponegoro Nomor 16, Sungailiat Bangka \\ ${ }^{b}$ STISIPOL Pahlawan 12 Sungailiat, Jalan Diponegoro Nomor 16, Sungailiat Bangka \\ 'STISIPOL Pahlawan 12 Sungailiat, Jalan Diponegoro Nomor 16, Sungailiat Bangka \\ ${ }^{1}$ sudarcun1234@ gmail.com*; wmira746@ gmail.com; zakiyudin.fikri@ stisipolp12.ac.id \\ *zakiyudin.fikri@stisipolp12.ac.id
}

\section{INFO ARTIKEL}

\section{Riwayat Artikel:}

Diterima: 08-08-2020

Disetujui:26-08-2020

\section{Kata Kunci: \\ 1.Implementasi program \\ 2.Kebijakan Publik \\ 3.Posbindu PTM}

Keyword:
1.Program Implementation
2.Public Pollicy
3.Posbindu PTM

\begin{abstract}
ABSTRAK
Abstrak: Penelitian ini membahas tentang Implementasi kebijakan program Posbindu PTM di Puskesmas Sinar Baru pada tahun 2018. Program Posbindu PTM merupakan salah satu program pemerintah Kabupaten Bangka dalam menanggapi masalah Penyakit Tidak Menular (PTM) di Puskesmas Sinar Baru. Adanya program Posbindu PTM ini bertujuan untuk menurunkan persentase Penyakit Tidak Menular (PTM). Tujuan penelitian ini adalah untuk mendeskripsikan serta menjelaskan implementasi kebijakan program Pos Pembinaan Terpadu Penyakit Tidak Menular (Posbindu PTM) di Puskesmas Sinar Baru pada tahun 2018. Jenis penelitian yang digunakan adalah deskriptif dengan pendekatan kualitatif. Teknik pengumpulan data menggunakan wawancara, observasi, dokumentasi dan trianggulasi. Teori yang digunakan yaitu teori Jones yang terdiri dari dimensi organisasi, dimensi interprestasi dan dimensi aplikasi serta untuk melihat faktor-faktor yang mempengaruhi keberhasilan implementasi, peneliti menggunakan teori Edward III yang terdiri dari komunikasi, sumber daya, disposisi dan struktur birokrasi. Berdasarkan hasil penelitian yang telah dilakukan peneliti menunjukkan bahwa para pelaksana Program Posbindu PTM personil kurang lengkap dan mempunyai tugas rangkap. Untuk faktor-faktor yang mempengaruhi keberhasilan komunikasi sangat mempengaruhi implementasi kebijakan program Posbindu PTM di Puskesmas Sinar Baru pada tahun 2018.
\end{abstract}

\begin{abstract}
This study discusses the implementation of Posbindu PTM program policies in the Sinar Baru Health Center in 2018. The Posbindu PTM program is one of the Bangka Regency government programs in responding to the problem of Non-Communicable Disease (PTM) in the Sinar Baru Health Center. The existence of the Posbindu PTM program aims to reduce the percentage of Non-Communicable Disease (PTM). The purpose of this study was to describe the implementation of the policy of the Post Integrated Disease Development Guidelines Program (Posbindu PTM) in Sinar Baru Health Center in 2018. The type of this research used was descriptive with a qualitative approach. Data collection techniques using interviews, observation, documentation and triangulation. The theory used is the theory of Jones which consists of organizational dimensions, dimensions of interpretation and application dimensions and to see the factors that influence the success of implementation, researchers use the theory of Edward III which consists of communication, resources, disposition and bureaucratic structure. Based on the results of research conducted by researcher's shows that the implementers of Posbindu PTM program personnel are incomplete and have multiple tasks. For the factors that influence the success of communication greatly affect the implementation of Posbindu PTM program policies at the Sinar Baru Health Center in 2018
\end{abstract}

\section{LATAR BELAKANG}

Indonesia menghadapi beban ganda dalam pembangunan kesehatan yaitu masih banyak penyakit infeksi yang harus ditangani dan kasus penyakit tidak menular (PTM) semakin meningkat. PTM merupakan penyakit dengan karakteristik tidak melalui suatu rantai penularan tertentu atau agent yang jelas. PTM mempunyai masa inkubasi yang panjang, penyakit dapat bersifat kronis atau berlarut - larut, multikausal dan terdapat kesulitan dalam diagnosis karena tanda-tanda penyakit mulai terlihat pada tahap lanjut sehingga sulit 
disembuhkan dan dapat menimbulkan kecacatan bahkan kematian. Penyandang PTM yang sudah masuk stadium lanjut memerlukan biaya pengobatan yang sangat besar, sehingga dapat membebani penderita, keluarga dan pemerintah.

Seperti yang dijelaskan Badan Pusat Data dan Informasi kementerian kesehatan Republik Indonesia pada tahun 2012 Penyakit Tidak Menular (PTM) menjadi penyebab utama kematian secara global.

Berdasarkan data WHO menunjukkan bahwa dari 57 juta kematian yang terjadi di dunia pada tahun 2008, sebanyak 36 juta atau hampir dua pertiganya disebabkan oleh penyakit tidak menular. PTM Juga membunuh penduduk dengan usia yang lebih muda. Di negaranegara dengan tingkat ekonomi rendah dan menengah, dari seluruh kematian terjadi pada orang-orang berusia kurang dari 60 tahun, 29\% disebabkan oleh PTM, sedangkan di Negara-negara maju, menyebabkan 13\% kematian. Proporsi penyebab kematian PTM pada orang-orang berusia kurang dari 70 tahun, penyakit Cardiovaskular merupakan penyebab terbesar (39\%), diikuti kanker (27\%), sedangkan penyakit pernafasan kronis, penyakit pencernaan dan PTM yang lain bersama-sama menyebabkan sekitar 30\% kematian, serta $4 \%$ kematian disebabkan diabetes.

Dibuktikan dengan berita yang disampaikan Badan Penelitian dan Pengembangan Kesehatan melalui hasil riset kesehatan dasar atau riskesda 2018 melalui media massa onlie suara.com pada November 2018 menunjukkan bahwa prevalensi penyakit tidak menular mengalami kenaikan jika dibandingkan dengan Riskesdas 2013, antara lain kanker, stroke, penyakit ginjal kronis, diabetes melitus, dan hipertensi. Dijelaskan Kepala Badan Penelitian dan Pengembangan Kesehatan, Siswanto, prevalensi kanker naik dari 1,4 persen (Riskesdas 2013) menjadi 1,8 persen di 2018 dengan prevalensi tertinggi di Provinsi DI Yogyakarta. Begitu pula dengan prevalensi stroke naik dari 7 persen menjadi 10,9 persen, sementara penyakit ginjal kronik naik dari 2 persen menjadi 3,8 persen. Berdasarkan pemeriksaan gula darah, prevalensi diabetes melitus naik dari 6,9 persen menjadi 8,5 persen; dan hasil pengukuran tekanan darah, hipertensi naik dari 25,8 persen menjadi 34,1 persen.

Berdasarkan penjelasan Badan Penelitian dan Pengembangan Kesehatan dapat diketahui bahwa meningkatnya jumlah penyakit tidak menular yang ada di Indonesia setiap pertahunnya. Hal ini dikarenakan kurangnya kesadaran masyarakat maupun sosialisasi akan Penyakit Tidak Menular di wilayahnya masingmasing. Sehingga perlu kita ketahui bahwa penyakit tidak menular persentasenya lebih berbahaya dibandingkan dengan penyakit menular.

Penyakit tidak menular (PTM) terjadi akibat berbagai faktor resiko seperti merokok, diet konsumsi tidak sehat, kurang aktifitas fisik, dan konsumsi minuman beralkohol.
Faktor resiko tersebut akan menyebabkan terjadinya perubahan fisiologis di dalam tubuh manusia sehingga menjadi faktor risiko antara lain tekanan darah meningkat, gula darah meningkat, kolestrol darah meningkat dan obesitas yang dapat menyebabkan PTM dalam waktu berkelanjutan. Usaha pemerintah dalam menangani masalah kesehatan masyarakat pada penyakit tidak menular adalah dengan suatu program yang dikenal dengan istilah Pos Pembinaan Terpadu Penyakit Tidak Menular (Posbindu PTM). Hal ini sesuai dengan Peraturan Menteri Kesehatan Nomor 71 Tahun 2015 Tentang Penanggulangan Penyakit Tidak Menular. Tujuan dari program ini adalah meningkatkan peran serta masyarakat dalam pencegahan dan penemuan dini faktor risiko PTM.

Sesuai dengan Peraturan Menteri Kesehatan Republik Indonesia Nomor 71 tahun 2015 pasal 20 menjelaskan peran serta masyarakat yaitu:

1. Masyarakat baik secara perorangan maupun kelompok berperan aktif dalam penanggulangan PTM.

2. Peran serta masyarakat sebagaimana yang dimaksud pada ayat (1) dilaksanakan melalui kegiatan Upaya Kesehatan Berbasis Masyarakat (UKBM) dengan membentuk dan mengembangkan Pos Pembinaan Terpadu PTM (Posbindu PTM).

3. Pada Pos Pembinaan Terpadu PTM (Posbindu PTM) sebagaimana dimaksud pada ayat (2) dapat dikatakan kegiatan deteksi dini, monitoring dan tindak lanjut dini faktor risiko PTM secara mandiri dan berkesinambungan di bawah pembinaan Puskesmas.

Pada tahun 2016 jumlah Posbindu PTM yang ada diwilayah kerja Puskesmas Sinar Baru yaitu 7 Posbindu PTM. 1 di Kelurahan Sinar Baru, 2 di Kelurahan Sinar Jaya dan 4 di Kelurahan Matras. Jadi Puskesmas Sinar Baru mempunyai 7 Posbindu PTM di wilayah kerjanya. Permasalahan yang ditemukan yaitu kurang berjalan efektif dikarenakan minimnya peserta Posbindu PTM yang hadir dan sumber daya manusia atau pelaksana yang tidak selalu hadir pada setiap pertemuan.

Pemerintah daerah telah menetapkan programnya masing-masing, sama halnya dengan pemerintah daerah Kabupaten Bangka. Dengan adanya program Posbindu penyakit tidak menular, pemerintah berharap akan berkurangnya persentase penyakit tidak menular yang ada di Kabupaten Bangka. Pemerintah daerah Bangka melalui Dinas Kesehatan dan dilaksanakan oleh Puskesmas menghimbau untuk mengurangi angka persentasenya dengan mengajak masyarakat Kabupaten Bangka untuk bergerak aktif dan sadar mengenai tingkat kesehatan tersebut.

Puskesmas (Pusat Kesehatan Masyarakat) sebagai pelaksana program kesehatan, khusus Program Posbindu PTM ini sangat penting diperhatikan untuk 
pembangunan kesehatan masyarakat, khususnya Puskesmas Sinar Baru. Puskesmas Sinar Baru ini selalu menjunjung tinggi kegiatan program ini hingga mencapai peningkatan. Salah satunya ialah peningkatan dalam SPM (Standar Pelayanan Minimal) bidang kesehatan seperti skrinning kesehatan yang berusia memasuki 15 tahun sampai dengan 59 tahun. Mengapa demikian karena, kategori tersebut harus ditingkatkan sesuai dengan target SPM bidang kesehatan pemerintah daerah yaitu 100\% ( seratus persen) sesuai dengan Peraturan Bupati Bangka Nomor 16 A tahun 2015 tentang Standar Pelayanan Minimal bidang kesehatan di Kabupaten Bangka, dengan melalui Dinas Kesehatan Kabupaten Bangka dan dilaksanakan oleh pihak Puskesmas Sinar Baru.

Berdasarkan Penjelasan mengenai Program Pos Pembinaan Terpadu Penyakit Tidak Menular (Posbindu PTM), di Kabupaten Bangka Program Posbindu PTM ini telah didirikan sejak tahun 2015, ditetapkannya di Puskesmas Sinar Baru pada tahun 2016, karena kepengurusan program Posbindu PTM di Puskesmas Sinar Baru tersebut baru dijalankan oleh pemerintah daerah melalui Dinas Kesehatan. Banyak hal-hal yang menyangkut permasalahan yang ada di program ini yakni:

1. Kurangnya promotif dan preventif dari masyarakat atau pengurusnya sendiri.

2. Kurangnya partisipatif dari berbagai pihak.

3. Kurangnya sosialisasi diberbagai tempat yang sulit dijangkau, seperti didaerah-daerah terpencil.

4. Kurangnya informasi dan lain sebagainya.

Belum tercapainya target SPM bidang kesehatan yang telah ditetapkan oleh pemerintah daerah kepada Puskesmas Sinar Baru yang disebut penyelenggara kegiatan program tersebut.

Tabel 1

Target Spm Bidang Kesehatan Pencapaian Program Pobindu Ptm Di Puskesmas Sinar Baru Pada tahun 2016-2018

\begin{tabular}{|c|c|c|c|c|}
\hline $\begin{array}{c}\text { Target } \\
\text { capaian } \\
\text { SPM }\end{array}$ & Tahun & $\begin{array}{c}\text { Target } \\
\text { Puskesmas } \\
\text { Sinar Baru } \\
\text { yang } \\
\text { dibuat dari } \\
\text { Dinas } \\
\text { Kesehatan } \\
\text { Kabupaten } \\
\text { Bangka }\end{array}$ & $\begin{array}{c}\text { Realisasi } \\
\text { capaian } \\
\text { Puskesmas } \\
\text { Sinar Baru }\end{array}$ & $\begin{array}{c}\text { Persentase } \\
\text { hasil }\end{array}$ \\
\hline \multirow{3}{*}{$\begin{array}{l}100 \% \\
15-59 \\
\text { tahun }\end{array}$} & 2016 & & & \\
\hline & 2017 & 8.440 & 2.032 & $24 \%$ \\
\hline & 2018 & 8.474 & 4.916 & $58,01 \%$ \\
\hline
\end{tabular}

Sumber: Puskesmas Sinar Baru, pengelola program

Posbindu PTM Tahun 2018

Berdasarkan tabel diatas dapat dijelaskan bahwa sasaran standar pelayanan SPM bidang kesehatan sesuai dengan Peraturan Menteri Kesehatan Nomor 4 Tahun 2019 Tentang Standar Teknis Pemenuhan Mutu Pelayanan Dasar Pada Standar Pelayanan Minimal Bidang Kesehatan, dan Peraturan Bupati nomor 16 A Tahun 2015 Tentang Standar Pelayanan Minimal Bidang
Kesehatan; pelayanan itu mencakup yaitu 1) pelayanan usia produktif 15-59 tahun, 2) pelayanan penderita Hipertensi dan 3) pelayanan penderita Diabetes Melitus, yang dikategorikan oleh pemerintah daerah melalui Dinas Kesehatan Kabupaten Bangka dan dilaksanakan oleh Puskesmas Sinar Baru yaitu capaian 100\% (seratus persen) sasaran usia 15-59 tahun. Namun dikarenakan capaian yang kurang dari apa yang diinginkan maka Dinas kesehatan Kabupaten Bangka menurunkan target menjadi kisaran pada tahun 2016 belum diketahui dikarenakan belum ditetapkannya standar pelayanan minimal, namun pada tahun 2017 menjadi (8.440 dengan capaian 2.032 persentase 24\%), pada tahun 2018 (8.474 dengan capaian 4.916 persentase $58,01 \%$ ). Target tersebut bertambah atau menurun dikarenakan jumlah penduduk disekitar wilayah cakupan Puskesmas Sinar Baru.

Persentase yang ditetapkan oleh pemerintah daerah Kabupaten Bangka belum memenuhi capaiannya yaitu dengan target 100\% (seratus persen). Dalam hasil akhir yaitu pada tahun 2018 dari perhitungan akumulatif dengan persentase $58,01 \%$, sehingga bisa dikatakan bahwa Standar Pelayanan Minimal yang dilakukan sejauh ini masih setengahnya dari apa yang diharapkan sebelumnya oleh pemerintah daerah sesuai dengan Peraturan Bupati Bangka Nomor 16 A Tahun 2015 tentang Standar Pelayanan Minimal bidang kesehatan di Kabupaten Bangka.

Berdasarkan permasalahan pada latar belakang diatas, maka peneliti merasa layak untuk melakukan penelitian, 1. Untuk mengetahui implementasi kebijakan program Pos Pembinaan Terpadu Penyakit Tidak Menular (Posbindu PTM) di puskesmas Sinar Baru pada tahun 2018 dan 2. Untuk mengetahui faktor-faktor yang mempengaruhi implementasi kebijakan program Pos Pembinaan Terpadu Penyakit Tidak Menular (Posbindu PTM) di puskesmas Sinar Baru pada tahun 2018

\section{TINJAUAN PUSTAKA}

Menurut Riant Nugroho (2017:107-108) kebijakan publik secara sektor adalah kebijakan yang dibuat sesuai dengan bidang yang diatur oleh kebijakan tersebut. Menurut Riant Nugroho (2017:182-183), kebijakan publik sendiri merupakan bentuk dinamik dari tiga dimensi kehidupan setiap Negara bangsa yaitu: 1 . Dimensi politik, karena kebijakan publik merupakan bentuk paling nyata dari sistem politik yang dipilih. Politik demokratis memberikan hasil kebijakan publik yang berproses secara demokratis dan dibangun untuk kepentingan kehidupan bersama, bukan orang se-orang atau satu atau beberapa golongan saja. 2. Dimensi hukum, karena kebijakan publik merupakan fakta hukum dari Negara, sehingga kebijakan publik mengikat seluruh rakyat dan juga seluruh penyelenggara Negara, terutama penyelenggara pemerintah. Fakta ini ditekankan karena hukum yang buruk adalah hukum yang berlaku untuk rakyat (terutama rakyat kecil) dan 
bukan untuk pembuat atau penegak hukum (atau"rakyat besar"). 3. Dimensi manajemen, karena kebijakan publik perlu untuk dirancang atau direncanakan, dilaksanakan melalui berbagai organisasi dan kelembagaan, dipimpin oleh pemerintah beserta organisasi eksekutif yang dipimpinnya, yaitu birokrasi bersama-sama dengan rakyat, dan untuk mencapai hasil yang optimal, maka implementasi kebijakan publik harus dikendalikan. Fungsi perencanaan, pengorganisasian, kepemimpinan, dan pengendalian adalah fungsi manajemen.

Van Meter dan Van Horn dalam Winarno (2012:149) mendefinisikan implementasi sebagai tindakan-tindakan yang dilakukan oleh individu-individu atau kelompok pemerintah maupun swasta yang diarahkan untuk mencapai tujuan-tujuan yang telah ditetapkan dalam keputusan-keputusan kebijakan sebelumnya. Sedangkan Grindle dalam Agustino (2008:139) mengatakan bahwa pengukuran keberhasilan implementasi dapat dilihat dari prosesnya, dengan mempertanyakan apakah pelaksanaan program sesuai dengan yang telah ditentukan yaitu melihat pada action program dari individual projects dan yang kedua apakah tujuan program tersebut tercapai.

Edward III dalam Subarsono, (2011:90) berpandangan bahwa implementasi kebijakan dipengaruhi oleh empat variabel, yaitu a) Komunikasi, yaitu keberhasilan implementasi kebijakan mensyaratkan agar implementor mengetahui apa yang harus dilakukan, dimana yang menjadi tujuan dan sasaran kebijakan harus ditransmisikan kepada kelompok sasaran (target group), sehingga akan mengurangi distorsi implementasi. b) Sumberdaya, meskipun isi kebijakan telah dikomunikasikan secara jelas dan konsisten, tetapi apabila implementor kekurangan sumberdaya untuk melaksanakan, maka implementasi tidak akan berjalan efektif. Sumber daya tersebut dapat berwujud sumber daya manusia, misalnya kompetensi implementor dan sumber daya finansial. c) Disposisi, adalah watak dan karakteristik yang dimiliki oleh implementor, seperti komitmen, kejujuran, sifat demokratis. Apabila implementor memiliki disposisi yang baik, maka implementor tersebut dapat menjalankan kebijakan dengan baik seperti apa yang diinginkan oleh pembuat kebijakan.

Ketika implementor memiliki sikap atau perspektif yang berbeda dengan pembuat kebijakan, maka proses implementasi kebijakan juga menjadi tidak efektif. d) Struktur Birokrasi, Struktur organisasi yang bertugas mengimplementasikan kebijakan memiliki pengaruh yang signifikan terhadap implementasi kebijakan. Aspek dari struktur organisasi adalah Standard Operating Procedure (SOP) dan fragmentasi. Struktur organisasi yang terlalu panjang akan cenderung melemahkan pengawasan dan menimbulkan red-tape, yakni prosedur birokrasi yang rumit dan kompleks, yang menjadikan aktivitas organisasi tidak fleksibel.
Menurut Van Meter dan Van Horn dalam Riant Nugroho (2017:737) adalah, model ini mengandaikan bahwa implementasi kebijakan berjalan secara linear dari kebijakan publik, implementor, kinerja kebijakan publik. Beberapa variabel yang dimasukkan sebagai v 1)

Menurut Van Meter dan Van Horn dalam Riant Nugroho (2017:737) adalah, model ini mengandaikan bahwa implementasi kebijakan berjalan secara linear dari kebijakan publik, implementor, kinerja kebijakan publik. Beberapa variabel yang dimasukkan sebagai variabel yang mempengaruhi kebijakan publik adalah variabel: ariabel yang mempengaruhi kebijakan publik adalah variabel: a. Aktivitas implementasi dan komunikasi antar organisasi, b. Karakteristik dari agen pelaksana / implementor, c. Kondisi ekonomi, sosial dan politik, dan d. Kecendrungan (disposition) dari pelaksana/implementor.

Pada penelitian Implementasi kebijakan program Pos Pembinaan Terpadu Penyakit Tidak Menular (Posbindu PTM) di Puskesmas Sinar Baru pada tahun 2018, peneliti menggunakan 2 (dua) teori. Pertama menggunakan teori Jones dalam Widodo (2007:89-96) yang terdiri dari organisasi merupakan suatu upaya untuk menetapkan dan menata kembali sumber daya (Resources), unit-unit (units), dan metode-metode (methods) yang mengarah pada upaya mewujudkan (merealisasikan) kebijakan hasil (outcame) sesuai dengan apa yang menjadi tujuan dan sasaran kebijakan. Interprestasi merupakan aktivitas interprestasi (penjelasan) substansi dari suatu kebijakan dalam bahasa yang lebih operasional dan mudah dipahami sehingga dapat dilaksanakan dan diterima oleh para pelaku dan sasaran kebijakan. Aplikasi merupakan aktivitas penyediaan pelayanan secara rutin, pembayaran atau lainnya sesuai dengan tujuan dan sasaran kebijakan yang ada. Dapat disimpulkan bahwa dari beberapa pengertian organisasi, interprestasi dan aplikasi tersebut ialah sebagai penunjang keberhasilan suatu sasaran kebijakan. Kedua teori George Edward III dalam Nugroho (2017:747), yang terdiri dari 4 variabel yaitu komunikasi diartikan sebagai proses penyampaian informasi dari komunikator kepada komunikaan. Komunikasi kebijakan berarti merupakan proses penyampaian informasi kebijakan dari pembuat kebijakan (policy makers) kepada pelaksana kebijakan (policyimplementors). Sumber daya disebutkan meliputi sumber daya manusia, sumber daya keuangan, dan sumber daya peralatan (gedung, peralatan, tanah, dan suku cadang lain) yang diperlukan dalam melaksanakan kebijakan. Disposisi merupakan kemauan, keinginan, dan kecendrungan para pelaku kebijakan untuk melaksanakan kebijakan secara sungguh-sungguh sehingga apa yang menjadi tujuan kebijakan dapat diwujudkan. Struktur birokrasi mecakup aspek-aspek seperti struktur organisasi, pembagian kewenangan, hubungan antar unit-unit organisasi yang ada dalam organisasi yang bersangkutan, dan hubungan organisasi 
dengan organisasi luar dan sebagainya. Penggunaan teori tersebut dapat membantu peneliti untuk menganalisis implementasi kebijakan program Posbindu PTM secara lebih mendalam dan rinci

\section{METODE PENELITIAN}

Penelitian ini menggunakan deskriptif dengan pendekatan kualitatif. Penelitian kualitatif tentang riset yang bersifat deskriptif dan cenderung menggunakan analisis. Proses dan makna lebih ditonjolkan dalam penelitian kualitatif. Penelitian kualitatif bertujuan memperoleh gambaran seutuhnya mengenai suatu hal menurut pandangan manusia yang diteliti.

Penelitian kualitatif berhubungan dengan ide, persepsi, pendapat atau kepercayaan orang yang diteliti dan kesemuanya tidak dapat diukur dengan angka. Dalam penelitian ini, peneliti menggunakan jenis dan sumber data primer dan data sekunder. Pengumpulan data melalui metode wawancara, observasi, dokumentasi dan trianggulasi.

Informan penelitian terdiri dari 7 orang yakni 1 orang koordinator program Posbindu PTM di Dinas Kesehatan Kabupaten Bangka, 1 orang Koordinator program Posbindu PTM di Puskesmas Sinar Baru, 3 orang pelaksana program Posbindu PTM di Puskesmas Sinar Baru, dan 2 orang penerima layanan program Posbindu PTM dan Masyarakat. Pada penelitian ini observasi dilakukan dengan peneliti secara langsung mengamati peristiwa yang ada dilapangan. Observasi yang dilakukan seperti di Puskesmas Sinar Baru dan tempat-tempat lain yang mendukung penelitian yang akan di observasi disini ialah, proses kegiatan Posbindu PTM tersebut secara langsung dengan mengamati pemeriksaan PTM yaitu pemeriksaan Penyakit Tidak Menular, kemudian apa saja yang masuk pengecekan yang tidak menular ini dan juga standar pelayanan yang mereka berikan kepada masyarakat maupun lainnya dalam kegiatan tersebut berlangsung. Pada tahap dokumentasi ini peneliti sebaik mungkin menggunakan tahap pendokumentasian seperti pengambilan foto, catatan yang kemudian dikumpulkan untuk melengkapi tahap hasil penyelesaian. Disini peneliti mengambil gambar proses berlangsungnya kegiatan Posbindu PTM di sejumlah wilayah Sinar Baru,

Kemudian mencatat apa saja yang perlu di tanyakan untuk bahan penelitian yang dibutuhkan. Terakhir trianggulasi, dalam penelitian ini, data diperoleh dari wawancara, observasi dan dokumentasi kemudian digabungkan dan akan menentukan hasil yang diinginkan oleh peneliti tersebut. Pengumpulan ini bertujuan agar peneliti bisa mengetahui standar pelayanan minimal bidang kesehatan yang belum mencapai target yang ditentukan oleh pemerintah daerah dengan alasan yang logis.

\section{PEMBAHASAN}

Implementasi kebijakan program Posbindu PTM merupakan kegiatan monitoring dan deteksi dini faktor resikoPTM terintegrasi serta gangguan akibat kecelakaan dan tindakan kekerasan dalam rumah tangga yang dikelola oleh masyarakat melalui pembinaan terpadu. Kemudian faktor-faktor yang mempengaruhi implemeentasi kebijakan program Posbindu PTM. Penelitian ini menggunakan 2 teori yaitu teori Jones dalam Widodo yang terdiri dari organisasi, interprestasi dan aplikasi. Teori Edward III yang terdiri dari komunikasi, sumber daya, disposisi dan struktur birokPeraturan Menteri kesehatan Republik Indonesia Nomor 71 Tahun 2015 tentang penanggulangan Penyakit Tidak Menular. Penyakit Tidak Menular yang selanjutnya disingkat PTM adalah penyakit yang tidak bisa ditularkan dari orang ke orang, yang perkembangannya berjalan perlahan dalam jangka waktu yang panjang (kronis). Penanggulangan PTM adalah upaya kesehatan yang mengutamakan aspek promotif (peningkatan) dan preventif (pencegahan) tanpa mengabaikan aspek kuratif (penyembuhan) dan rehabilitative (pemulihan) serta paliatif yang ditujukan untuk menurunkan angka kesakitan, kecacatan, dan kematian yang dilaksanakan secara komprehensif, efektif, efisien, dan berkelanjutanrasi.

Posbindu PTM yang telah berjalan sejak tahun 2015 di wilayah kerja Puskesmas Sinar Baru ini merupakan kegiatan rutin pemeriksaan kesehatan sebagai deteksi dini PTM yang dilaksanakan setiap bulannya sebanyak satu kali oleh masing-masing Posbindu PTM sampai saat ini. Pemerintah semakin memprioritaskan Program PTM yang ditandai dengan terbitnya Peraturan Menteri Kesehatan Nomor 4 Tahun 2019 tentang Standar Pelayanan Minimal bidang kesehatan, dimana salah satu isinya berbunyi” setiap warga negara Indonesia usia 15 sampai dengan 59 tahun mendapatkan skrining kesehatan sesuai standar"(Republik Indonesia,2019), sehingga ditargetkan kunjungan Posbindu PTM mulai tahun 2017 adalah 100\%, maka posbindu PTM semakin digencarkan lagi. Adapun Posbindu PTM mulai tahun 2016 belum ada pos dikelurahan, selanjutnya 2017 sampai dengan 2018 berjumlah 7 Posbindu PTM yang tersebar di setiap 3 Kelurahan dalam wilayah kerja Puskesmas Sinar Baru.

\begin{tabular}{|c|c|c|c|c|}
\hline $\begin{array}{c}\text { Target } \\
\text { capaian } \\
\text { SPM }\end{array}$ & Tahun & $\begin{array}{c}\text { Target Puskesmas } \\
\text { Sinar Baru yang } \\
\text { dibuat dari Dinas } \\
\text { Kesehatan Kabupaten } \\
\text { Bangka }\end{array}$ & $\begin{array}{c}\text { Realisasi } \\
\text { capaian } \\
\text { Puskesmas } \\
\text { Sinar Baru }\end{array}$ & $\begin{array}{c}\text { Persentase } \\
\text { Hasil }\end{array}$ \\
\hline $\begin{array}{c}100 \% \\
15-59\end{array}$ & 2016 & & & \\
\cline { 2 - 5 } tahun & 2017 & 8.440 & 2.032 & $24 \%$ \\
\cline { 2 - 5 } & 2018 & 8.474 & 4.916 & $58,01 \%$ \\
\hline
\end{tabular}

Sumber : Puskesmas Sinar Baru, pengelola program Posbindu PTM pada 
Implementasi kebijakan program Posbindu PTM sebagai berikut:

Dalam rizki dan indah jurnal publika volume 5 nomor 5 tahun 2017 menjelaskan Sasaran Posbindu PTM dibagi menjadi 3 kelompok yaitu sasaran utama, sasaran antara, dan sasaran penunjang. Pendekatan terhadap ketiga sasaran tersebut dilakukan satu persatu berurutan namun harus dilakukan secara integratif selama proses pelaksanaan. 1) Sasaran utama. Sasaran utama adalah masyarakat sehat, berisiko dan penyandang PTM berusia 15 tahun ke atas, 2) sasaran antara, Sasaran antara adalah individu/kelompok masyarakat yang dapat menjadi agen pengubah faktor risiko PTM, dan dapat menciptakan lingkungan yang kondusif untuk mencegah dan mengendalikan faktor risiko PTM melalui penyelenggara Posbindu PTM. Sasaran antara tersebut adalah petugas kesehatan baik pemerintah maupun swasta, tokoh panutan masyarakat, anggota masyarakat yang peduli PTM. 3) Sasaran penunjang. Sasaran penunjang adalah individu, kelompok/ organisasi/ lembaga masyarakat dan profesi, lembaga pendidikan dan lembaga pemerintah yang diharapkan dapat memberi dukungan baik dukungan kebijakan, teknologi dan ilmu pengetahuan, material maupun dana, untuk terwujudnya Posbindu PTM dan keberlangsungan aktifitasnya. Mereka antara lain adalah pimpinan daerah/ wilayah, Perusahaan, Lembaga Pendidikan, Organisasi Profesi, dan Penyandang Dana.

Adapun hasil penelitian dan pembahasan tentang Implementasi kebijakan program Posbindu PTM di Puskesmas Sinar Baru pada tahun 2018 dan Faktorfaktor yang mempengaruhi Implementasi kebijakan program Posbindu PTM di Puskesmas Sinar Baru pada tahun 2018, diuraikan dalam berdasarkan teori Implementasi kebijakan dan Faktor-faktor yang mempengaruhi implementasi kebijakan program sebagai berikut:

\section{1) Organisasi}

Pada sebuah tahap organisasi ini pastinya diperlukan penataan sumber daya yang merupakan salah satu bentuk untuk mengatur kembali dan menggunakan sumber daya yang dimiliki secara maksimal agar tujuan organisasi tersebut tercapai.

Suatu upaya untuk menetapkan dan menata kembali sumber daya, unit-unit, dan metode-metode yang mengarah pada upaya mewujudkan/ merealisasikan kebijakan menjadi hasil (outcame) sesuai dengan apa yang menjadi tujuan dan sasaran kebijakan. Pada dimensi organisasi, dapat dilihat pada program Posbindu PTM bahwa, berdasarkan hasil penelitian yang dilakukan oleh peneliti, bahwa kebijakan program posbindu PTM ini belum tercapai dengan baik, berdasarkan hasil penelitian kualitas dan kuantitas baik dari tenaga medis maupun kesehatan lainnya dalam memberikan pelayanan sudah cukup baik, tetapi yang menjadi kendala adalah kurangnya tenaga medis yang diharapkan bisa datang pada setiap pertemuan Posbindu PTM.

Untuk sumber daya informasi Posbindu PTM seharusnya disosialisasikan kepada kader agar mempermudah menerima informasi dan melakukan pelaporan dan perlu penambahan buku pedoman untuk kader pendamping untuk lebih mempermudah penyampaian materi kepada kelompok sasaran. Pada program Posbindu PTM, pelayanan tidak sesuai dengan prosedur 5 meja dikarenakan tenaga medis kurang. Sesuai dengan peraturan menteri kesehatan nomor 71 tahun 215, dikarenakan dalam hal sumber daya kepegawaian masih belum efektif dalam pelaksanaannya juga cara kerja dilapangannya dikarenakan petugas kesehatan mempunyai tugas rangkap sesuai dengan peraturann Bupati Bangka nomor 16 tahun 2015 dan peraturan Menteri kesehatan nomor 4 tahun 2019.

\section{2) Interprestasi}

Dimensi interprestasi dalam implementasi kebijakan program Posbindu PTM berdasarkan hasil penelitian yang dilakukan oleh peneliti, bahwa dalam penyampaian pendapat dari pihak Puskesmas dan Dinas Kesehatan Kabupaten Bangka maka penyampaian sosialisasi informasi mengenai program tersebut sudah cukup baik. Pada pelaksanaan program Posbindu PTM, pihak pemerintah Kabupaten Bangka sudah memberikan sosialisasi program tersebut, sosialisasi tersebut diberikan 5 kali dalam satu tahun kepada para pelaksana dengan baik. Pencatatan dan pelaporan kegiatan Posbindu PTM dilakukan oleh kader, para pelaksana membagikan buku catatan untuk diisi guna pengarsipan data pasien PTM yang telah terdata setiap tahunnya.

Pemangku kepentingan pada program Posbindu PTM difokuskan pada kepala desa atau lurah, berperan dengan memotivasi warga untuk mengikuti Posbindu PTM, membantu mengusahakan pengadaan fasilitas untuk pelaksanaan Posbindu PTM, namun masih ada beberapa pemangku kepentingan yang belum memahami mengenai Posbindu PTM sehingga jarang melakukan koordinasi mengenai Posbindu PTM dan belum bisa membantu penganggaran dana untuk pelaksanaan Posbindu PTM. Untuk mendukung pelaksanaan Posbindu PTM membutuhkan pembiayaan yang memadai, baik dana mandiri, kelompok masyarakat, kemitraan melalui program CSR (Corporate Social Responsibility) serta bantuan donatur yang peduli terhadap permasalahan PTM. Namun, pihak Puskesmas Sinar Baru belum secara optimal dalam memberikan sosialisasi kepada para penerima layanan dan masyarakat mengenai program Posbindu PTM tersebut.

\section{3) Aplikasi}

Pada dimensi aplikasi dalam implementasi kebijakan program Posbindu PTM berdasarkan hasil penelitian yang dilakukan oleh peneliti, bahwa untuk pelaksanaan program Posbindu PTM ini sudah baik, hal ini dikarenakan para pelaksana program melaksanakan 
sesuai dengan penerapan yang dilakukan petugas dengan kunjungan kerumah-rumah warga. Pelayanan yang dilakukan tersebut untuk pasien yang berisiko hanya melayani 3 bulan sekali saja dalam satu tahun. Pelaksanaan Program Posbindu PTM menyesuaikan dengan sarana dan parasarana seadanya dan belum sesuai standar, yaitu 5 meja (RI,2012).

Salah satu upaya yang dilakukan Puskesmas Sinar Baru yaitu telah melakukan evaluasi setahun sekali dalam penyelenggaraan pelayanan publik. Selanjutnya hasil evaluasi digunakan sebagai feedback dalam upaya penyempurnaan penyelenggaraan layanan publik. Upaya tersebut dilakukan dengan survey oleh tim UPM (IKM), untuk melihat tingkat kepuasan masyarakat atas pelayanan yang diterimanya. Pada pembiayaan program Posbindu PTM ini berasal dari APBN, APBD dan BOK, untuk program Posbindu PTM tersebut, biasanya pemerintah mencairkan dana tersebut pada program ini sekitar 4 bulan sekali dalam setiap tahunnya untuk pembayaran honor perjalanan kader dan para pelaksana program Posbindu PTM.

Pelayanan ini dilaksanakan dengan rumah kerumah, tidak mempunyai gedung seperti program Posyandu, hal ini dikarenakan pelayanan ini dilakukan berdasarkan target yang ditentukan. Akan tetapi, para pelaksana mungkin mempunyai kendala karena masyarakat tidak mau periksa karena takut akan terdeteksi penyakitnya dan malas untuk datang ketempat sasaran program posbindu PTM tersebut.

Dukungan anggaran pelaksanaan Posbindu PTM tersebut berasal dari APBD dan BOK sesuai dengan peraturan Bupati Bangka Nomor 2 A tahun 2017, untuk dari yang lain belum bisa dikarenakan masyarakat di wilayah kerja Puskesmas Sinar Baru belum bisa bermitra dengan donatur dana yang lain. Berdasarkan penelitian pembiayaan untuk penyelenggaraan Posbindu PTM di wilayah Puskesmas Sinar Baru belum memenuhi SOP.

\section{Faktor-faktor yang mempengaruhi implementasi kebijakan program Posbindu PTM sebagai berikut:}

\section{[1] Komunikasi}

Penyampaian informasi perlu dilaksanakan kepada para pelaksana kebijakan. Perlu disampaikan kepada para pelaku kebijakan dapat mengetahui apa yang harus mereka persiapkan untuk menjalankan kebijakan tersebut sehingga tujuan dan sarana kebijakan dapat dicapai sesuai dengan yang diharapkan.

Pada dimensi komunikasi dalam implementasi kebijakan program berdasarkan hasil penelitian yang dilakukan oleh peneliti, bahwa dalam hal komunikasi belum cukup baik, dikarenakan para pelaksana program Posbindu PTM belum mendapatkan pelatihan secara optimal, sehingga dilapangan para pelaksana hanya memberikan sosialisasi yang mereka dapatkan di Dinas Kesehatan Kabupten Bangka dan tidak spesifik mungkin dalam memberikan penjelasan kepada kader dan juga penerima layanan.

Terdapat kendala pada proses komunikasi dan koordinasi, yaitu banyak masyarakat yang keliru dan belum mengetahui seutuhnya program dan tujuan dari program Posbindu PTM, sehingga pelaksanaan Posbindu PTM mirip dengan pelaksanaan Posyandu Lansia. Penyaluran komunikasi yang dilakukan dalam hal implementasi program Posbindu PTM dilakukan melalui pertemuan antara kader dan petugas Puskesmas Sinar Baru membahas mengenai pelaksanaan dan hal penting lainnya terkait dengan implementasi program Posbindu PTM di wilayah kerja puskesmas Sinar Baru.

Komunikasi yang baik akan menghasilkan implementasi yang efektif sesuai dengan tujuan dari program tersebut. Implementasi yang efektif dapat mempengaruhi dengan baik apabila pihak terlibat dalam implementasi program Posbindu PTM mengetahui tugasnya sehingga lebih memperhatikan penyampaian informasi dalam proses komunikasi.

\section{[2] Sumber daya}

Sumber daya manusia sangat diperlukan dalam pelaksanaan proses kegiatan, sama halnya dengan program Posbindu PTM. Tentu saja dalam hal sumber daya sangat diperlukan untuk kelancaran sebuah kegiatan pelaksanaan secara langsung. Pada dimensi sumber daya dalam implementasi kebijakan program Posbindu PTM bahwa berdasarkan hasil penelitian yang dilakukan oleh peneliti, dalam pelaksanaan sumber daya belum cukup baik dikarenakan masih banyak kekurangan anggota pelaksana Posbindu PTM, kurangnya target capaian dari pemerintah yang harus dicakup oleh pelaksana program Posbindu PTM dan juga masyarakat masih malas dan malu, takut dalam pengecekan kesehatan pada program Posbindu PTM.

Pada program ini diharuskan dalam pelaksanaan kegiatan para petugas harus lengkap, namun kadangkala para pelaksana program tersebut masih kekurangan anggota pelaksana dari instansi Puskesmas Sinar Baru, hal ini dikarenakan petugas yang ada di program ini mempunyai tugas rangkap di instansi Puskesmas Sinar Baru. Hal ini juga tidak menyangkut soal pendidikan dari tenaga kesehatan yang ada di Puskesmas Sinar Baru, bahwa jumlah Sumber daya manusia ada 28 PNS dan 15 tenaga Honorer.

Pendidikan terakhir terbanyak yaitu 18 tenaga dengan pendidikan akhir DIII. Jenis tenaga fungsional masih kurang, paramedis yang berpendidikan DIII sekitar 75\%. Oleh karena itu masalah ini akan mempengaruhi suatu program yang dijalankan untuk mencapai suatu keberhasilan dikarenakan keterbatasan dan keahlian dalam bidangnya masing-masing (Renstra Puskesmas Sinar Baru 2016). Angaran tersebut berasal dari dana APBD, APBN, dan BOK, masing-masing dana tersebut digunakan untuk honor perjalanan para 
pelaksana dan kader kemudian digunakan untuk pembelian alat-alat kesehatan.

Peralatan yang digunakan sudah sesuai dengan SOP dari Dinas Kesehatan Kabupaten Bangka maupun Puskesmas Sinar Baru, pada kegiatan ini para pelaksana selalu lengkap dalam membawa peralatan yang akan digunakan di lapangan untuk memudahkan dalam pemeriksaan FR-PTM. Program ini, sudah sesuai dengan kebijakan yaitu Peraturan Menteri Kesehatan Nomor 71 Tahun 2015 yang dimuat dalam SOP surveilans PTM di Dinas Kesehatan Kabupaten Bangka. Program Posbindu PTM mengikuti alur dengan kebijakan dari pemerintah daerah Kabupaten Bangka.

\section{[3] Disposisi}

Pada implementasi kebijakan ingin berhasil secara efektif dan efisien, para pelaksana tidak hanya mengetahui apa yang harus dilakukan dan mempunyai kemampuan untuk melakukan kebijakan tersebut, tetapi mereka juga harus mempunyai kemauan untuk melaksanakan kebijakan tersebut. Dimensi disposisi dalam implementasi kebijakan program, berdasarkan hasil penelitian yang dilakukan oleh peneliti, bahwa dalam dimensi disposisi dengan melihat sikap pelaksana sudah baik dan ramah, hal ini terlihat dari para pelaksana Posbindu PTM sudah melakukan tugas sesuai dengan tupoksinya masing-masing, hanya saja dalam pemeriksaan lab, tensi dan mata, mereka harus bertukar posisi mengingat kurangnya personil dalam program ini. Pelaksana dibawahi oleh UKBM dalam pengembangan yang lebih kompeten di bidangnya, dalam masalah kader pun sudah cukup lengkap sesuai dengan tugasnya masing-masing.

Minimnya tingkat kesadaran untuk menjadi petugas sosial sehingga berdampak pada penumpukan tugas kader. Sikap dan komitmen untuk pelaksana Posbindu PTM, tenaga kesehatan maupun pendamping Posbindu PTM sudah baik dan ramah terhadap masyarakat. Tidak ada isentif dalam program Posbindu PTM, hanya saja mendapat honor perjalan dinas, honor tersebut diterima setiap 4 bulan sekali dalam 1 tahun, sama halnya juga dengan kader-kader Posbindu PTM.

\section{[4] Struktur birokrasi}

Sebuah persoalan program pastinya didalam setiap perencanaan tidak lepas dari struktur, dikarenakan pada progam-program yang berjalan harus mengikuti alur arahan yang sesuai dengan apa yang diperintahkan oleh kebijakan. Oleh karena itu struktur birokrasi dalam sebuah program menjadi penetu dalam sebuah penunjang alur kegiatan program yang berjalan secara optimal. Pada dimensi struktur birokrasi dalam implementasi kebijakan program berdasarkan hasil penelitian yang dilakukan oleh peneliti, bahwa implementasi kebijakan program Posbindu PTM di puskesmas Sinar Baru dan Dinas Kesehatan Kabupaten Bangka sudah cukup baik. Koordinasi itu diakukan setiap pelaporan hasil kunjungan pemeriksaan, kemudian dievaluasi oleh pihak Dinas Kesehatan.

Masyarakat juga menerima layanan dari pemeriksaan program tersebut sesuai dengan penjadwalan yang dibuat oleh para pelaksana di Puskesmas Sinar Baru. pada program tersebut juga terdapat SOP yang sesuai dengan pelaksanaan kegiatan yang mereka laksanakan. Pertanggungjawaban atau fragmentasi petugas di Puksesmas Sinar Baru dilakukan dengan melaporkan kegiatan Posbindu PTM setiap bulan kepada Dinas Kesehatan Kabupaten Bangka. Pencatatan dan pelaporan pelaksanaan Posbindu PTM di wilayah kerja Puskesmas Sinar Baru memenuhi SOP, namun belum terlaksana secara optimal.

\section{SIMPULAN DAN SARAN}

Berdasarkan hasil penelitian dan pembahasan yang dilakukan peneliti, bahwa 1. Impelementasi kebijakan program Posbindu PTM yang dilihat dari beberapa dimensi yang dikemukakan oleh Charles Jones, ada tiga (3) yaitu: dimensi organisasi, dimensi interprestasi, dan dimensi aplikasi hasilnya belum tercapai dengan baik. Yang pertama pada dimensi organisasi sumber daya manusia, dalam pelaksanaan program Posbindu PTM belum dengan baik dikarenakan petugas mempunyai tugas rangkap dan kurang lengkap. Kedua, dimensi interprestasi cukup baik dikarenakan penyampaian sosialisasi pihak Dinas Kesehatan Kabupaten Bangka kepada pelaksana petugas kesehatan Puskesmas Sinar Baru cukup terealisasikan dengan baik. Dan yang terakhir ketiga dimensi aplikasi cukup tercapai dengan baik dikarenakan penerapan aktivitas Program Posbindu PTM kunjungan kerumah warga. 2. Faktor yang dapat mempengaruhi implementasi kebijakan program Posbindu PTM di Puskesmas Sinar Baru dapat dilihat dari teori yang digunakan peneliti yaitu teori yang dikemukakan oleh Edward III diantaranya komunikasi, sumber daya, disposisi dan struktur birokrasi sangat mempengaruhi Implementasi Kebijakan Program Posbindu PTM di Puskesmas Sinar Baru pada tahun 2018.

Dari paparan mengenai implementasi kebijakan program Posbindu PTM di Puskesmas Sinar Baru pada tahun 2018, maka saran yang disampaikan oleh peneliti adalah 1) sosialisasi mengenai Posbindu PTM perlu ditingkatkan lagi dan lebih merata dengan menambah jangkauan penyuluhan. 2) dalam hal sumber daya manusia khusunya petugas kesehatan Puskesmas Sinar Baru untuk pengkoordinasian kelengkapan petugas kesehatan supaya cepat tercapainya komunikasi kepada kelompok sasaran. 3) dalam hal pelayanan pelru ditingkatkan lagi, khususnya pelayanan untuk mendata dan survey bagi warga yang belum mendapatkan pelayanan secara berkala. 


\section{DAFTAR RUJUKAN}

\section{Buku}

[1] Agustino, Leo. 2008. Dasar-Dasar Kebijakan Publik. Alfabeta. Bandung

[2] Bastian, Indra 2007. Sistem Akuntansi Sektor Publik. Jakarta: Salemba Empat.

[3] Lexy J, Moleong. 2007. Metodologi Penelitian Kualitatif. PT Remaja Rosadakarya. Bandung

[4] Narimawati Umi. 2008. Metodologi Penelitian Kualitatif dan Kuantitatif, Teori dan Aplikasi. Bandung: Agung Media Group

[5] Nugroho, Riant. 2017. Public Policy: Dinamika Kebijakan, Analisis Kebijakan, dan Manajemen Kebijakan. Elex Media Komputindo. Jakarta

[6] Subarsono, AG. 2011. Analisis kebijakan Publik: Konsep. Teori dan. Aplikasi. Pustaka Pelajar. Yogyakarta.

[7] Winarno, Budi. 2012. Kebijakan Publik (Teori, Proses dan Studi Kasus). PT. Buku Seru. Jakarta

\section{Jurnal}

[8] Febrian, Rizky. Indah Prabayati. 2017. Implementasi pelaksanaan pos pembinaan terpadu penyakit tidak

Menular (posbindu ptm) di puskesmas pucang sewu Kota Surabaya. Jurnal Publika Volume 5 Nomor 5 Program Studi Ilmu Administrasi Negara Fakultas Ilmu Sosial Universitas Negeri Surabaya.

[9] Kementrian kesehatan Republik Indonesia tahun 2014.

[10]Pusat data dan Informasi, kementrian kesehatan Republik Indonesia, Penyakit Tidak Menular, dipublikasikan pada: tahun, o1 November 2012. (https://pusdatin.kemkes.go.id/article/view/130102 o0029/penyakit-tidak-menular.html.)

[11] Peraturan Menteri Kesehatan Nomor 71 Tahun 2015 Tentang Penanggulangan Penyakit Tidak Menular.

[12]Peraturan Bupati Bangka Nomor 16 A Tahun 2015 tentang Standar Pelayanan Minimal di Kabupaten Bangka.

[13]Kerangka acuan kegiatan Posbindu PTM di Puskesmas Sinar Baru pada tahun 2017.

[14]Peraturan Menteri Kesehatan Republik Indonesia Nomor 4 Tahun 2019 tentang teknis pemenuhan mutu pelayanan dasar pada standar pelayanan minimal bidang kesehatan. 